
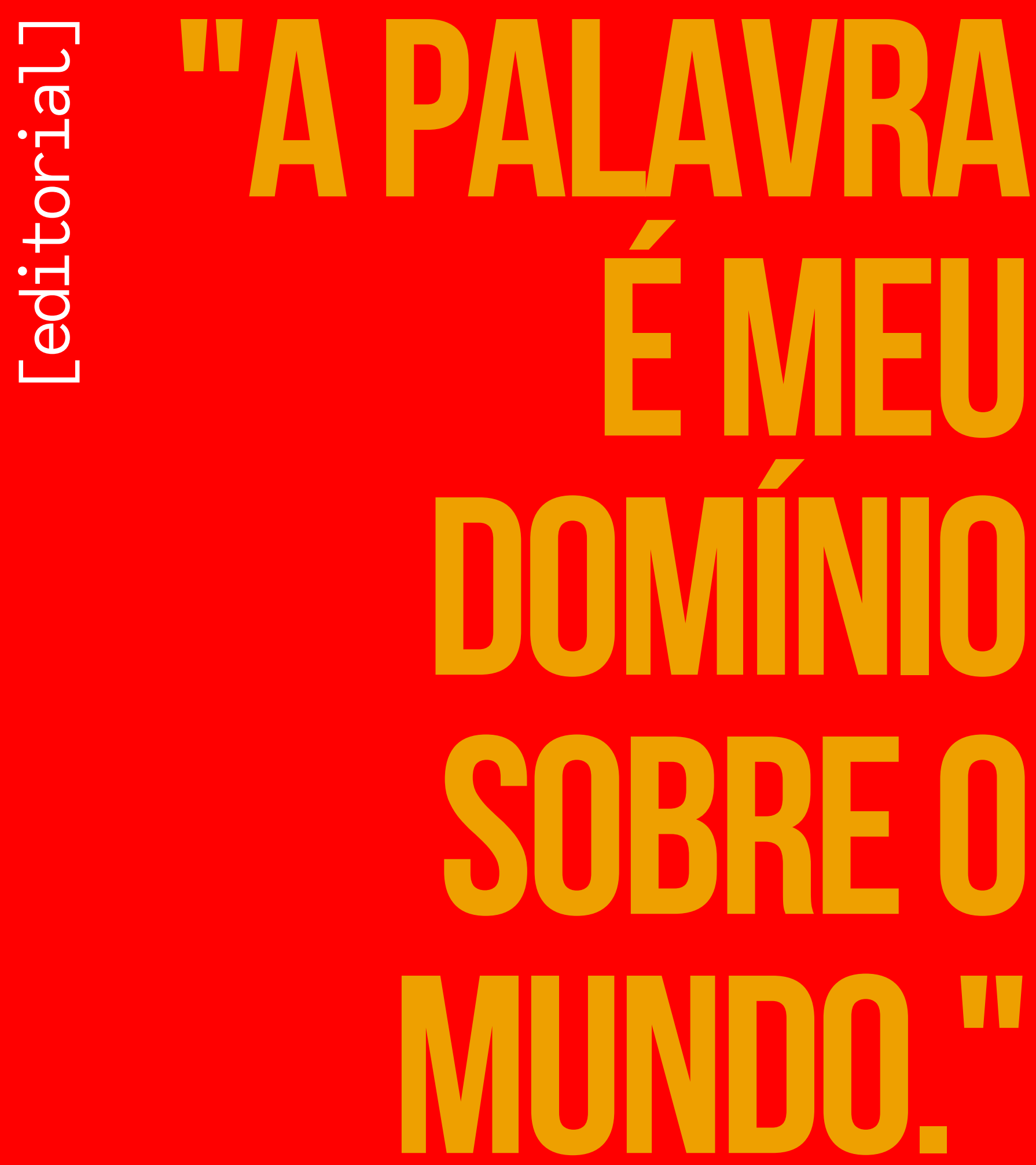

Carice Lispecto? 


\section{Articulações entre moda e literatura}

Gabriela Soares Cabral - Assistente editorial sênior

https://orcid.org/0000-0002-3410-3839

Maria Claudia Bonadio - Editora-chefe

https://orcid.org/0000-0001-9704-9780

Está no ar o número 28 da dObra[s]! Nesta primeira edição do ano de 2020, a revista chega com uma boa notícia: o periódico agora também faz parte do indexador Doaj-Directory of Apen Access Journals, uma base de dados com curadoria que reúne cerca de 12 mil revistas de acesso aberto que cobrem todas as áreas da ciência, tecnologia, medicina, ciências sociais e humanidades.

Nesta edição, o dossiê A moda na literatura e a literatura na moda, organizado pelas pesquisadoras Adriana Tulio Baggio (PUC-SP) e Geanneti Tavares Salomon (UNA-BH), reúne nove artigos que versam sobre a relação entre moda e literatura desde o período oitocentista até a contemporaneidade a partir de temas como a utilização do vestuário na construção de personagens e narrativas e o uso da literatura como influência para criadores de moda. Ainda como parte do dossiê, na seção Costuras, há a tradução inédita para o português do texto Dressing for success publicado em 2009 pela inglesa Clair Hughes, importante bibliografia acerca da articulação entre moda e literatura.

Além disso, na seção de artigos submetidos em fluxo contínuo, o número apresenta dois textos. Consumo e liberdade: a anglomania nas vésperas da Revolução Francesa, de autoria de Felipe Goebel, analisa a formação de uma cultura de consumo na França durante as décadas de 1770 e 1780, período em que se percebe uma busca por inspiração na Inglaterra por meio da emulação de costumes e trajes ingleses, visando demonstrar como a relação entre os dois países, nas décadas finais dos Setecentos, associou-se com os ideais revolucionários.

Em A beleza convulsiva do manequim: o corpo inorgânico da moda no Surrealismo, o autor Pedro Pinheiro Neves traça conexões entre as atitudes oitocentistas em relação ao corpo, ao vestuário e à moda e a fetichização de corpos realizadas por artistas como Man Ray, Hans Bellmer e Salvador Dalí, encontrando no uso da figura do manequim instanciações dos conceitos de beleza convulsiva e informe. 
A edição também conta com a resenha do livro A história na moda e a moda na história (São Paulo: Alameda, 2019), organizado por Camila Borges da Silva, Joana Monteleone e Paulo Debom. De autoria de Paulo Knauss, a resenha ressalta a riqueza da pesquisa sobre a história da moda no Brasil ao versar sobre uma obra que traz a produção de diferentes pesquisadores que se debruçam sobre a história do vestuário de modo a pensar os significados da moda na sociedade ao longo da história.

As exposições Histórias das mulheres: artistas até 1900 (realizada no Museu de Arte de São Paulo, em São Paulo, de 23 de agosto a 17 de novembro de 2019) e Alceu Penna - Inventando a moda do Brasil (realizada no Museu da Moda de Belo Horizonte, em Belo Horizonte, de 11 de dezembro de 2019 a 7 de junho de 2020) também ganharam resenhas para esta edição. Escrita por Gabriela Rodrigues Pessoa de Oliveira, a primeira aborda o trabalho das curadoras Julia Bryan-Wilson, Lilia Schwarcz e Mariana Leme em destacar as obras de mulheres artistas de diversas nacionalidades até o século XIX. Já a segunda, de autoria de Gabriela Ordones Penna, analisa a proposta de manter viva a memória de Alceu Penna e ressaltar sua importância para a história da moda com a exibição de 72 peças, entre roupas (réplicas e originais), acessórios, catálogos e croquis.

Boa leitura! 